\title{
Fearful to be an entrepreneur? A cross-country analysis of factors inhibiting entrepreneurship
}

\author{
Satwinder Singh ${ }^{\text {* }}$ \\ aDubai Business School, University of Dubai, Academic City, P.O. Box 14143, Dubai, UAE, ssingh@ud.ac.ae \\ ${ }^{*}$ Corresponding author.
}

Received: 1 September 2019, accepted: 24 September 2019, published: 11 October 2019.

\begin{abstract}
This paper is an empirical analysis that has explored personal and socio-economic factors that may inhibit entrepreneurial activity in two diverse countries--the UK and Brazil. Results show that British and Brazilian males, when they are skilled are less afraid to start a new venture. Results also show that this could be owing to a high status accorded in both the countries to new business start-ups. However, whereas media publicity may add to the fear factor of starting a business in the case of British entrepreneurs; it lessens the fear in the case of Brazilian entrepreneurs. Past failures seem to have no impact on British entrepreneurs, but such failures do seem to add to the fear in Brazilian entrepreneurs. Positive planning to start a new business adds to optimism for British entrepreneurs. Contrary to UK males, younger Brazilian males are less fearful of starting a new business.
\end{abstract}

Keywords: entrepreneur; small and medium-size business; logit model.

\section{INTRODUCTION}

There is a large amount of literature that explains why a person becomes an entrepreneur. The list includes the key characteristic of an entrepreneur such as the ability to exhibit traits of judgment in decision making (Casson, 2003; Knight, 1921). Judgment is a capacity for making a successful decision when no obviously correct model or decision rule is available (Casson, 2008). Other characteristics or 'traits' concern creativity and innovation (Schumpeter, 1911, 1954; Begley \& Boyd, 1986); foresight (Kirzner, 1973, 1979); imagination and daring (Begley and Boyd, 1986; Chandler \& Jansen 1992; Aldrich \& Wiedenmayer, 1993; Lumpkin \& Dess, 1996). These 'content-based' theories search for and emphasize specific traits within individuals that initiate, direct, and sustain entrepreneurial behavior. Other theories (Gilad \& Levine, 1986; Watson et al. 1998; Littunen, 2000; Morrison, 2000; Mckay, 2001; Orhan \& Scot, 2001; Alstete, 2003; McClelland et al., 2005; Doobs \& Hamilton, 2007) have focused on motivating 'push' factors such as lack of employment opportunities, dissatisfaction at work and supportive government initiatives - as well as 'pull' factors that relate to a desire for self-fulfillment and other personal rewards (Singh et.al. 2011; Mordi et.al. 2010; Singh et.al. 2010, 2011). There is, however, scant literature as to what stops a person from becoming an entrepreneur. Is it the case that the very factors that help make a person an entrepreneur also work in a perverse way and discourage him from becoming an entrepreneur? The question can be stated differently as follows. Assume that a person has the capacity to judge a situation well and take a decision to become an entrepreneur. Assume further that he is also creative, has the initiative, right connections and likes to achieve a sense of fulfillment by self-employing himself, as opposed to being in paid-employment, but still, for some reason, he/she is fearful to take the plunge to become an entrepreneur. Finding solutions to such a problem is a conundrum. We make an attempt in this exploratory paper and address this key research question with reference to two culturally diverse countriesthe United Kingdom and Brazil. The national and sub-national cultures of these two countries differ substantially. We hypothesize that some of these differences would show up in the statistical testing of the data. At the same time, some of the commonalities would also show up. This belief is based on the premise that the cultural values of entrepreneurs in two different settings would converge in similar or near similar business settings. Brazil has always been clubbed with the rest of the developing countries. However, the country is now clustered in the BRICS block of countries that are being hailed as emerging economic superpowers. If this is true then in a fastchanging economic landscape, engineered by entrepreneurs, we hope to see some convergence in personal and social values emerging between the UK and Brazil, taking the former as the benchmark. This paper assumes importance for several reasons. If the findings are correct and can hold for larger samples then there 
clearly is a case for providing assistance and support to prospective entrepreneurs on issues identified in the paper. This can help break the psychological barriers to setting up new ventures for economic growth.

The remainder of the paper is organized as follows. Section 2 presents a survey of work related to the theme under investigation. This is followed by section 3 that lists the derived hypotheses. Section 4 explains the data source and methodology. The results are discussed in section 5. Summary, conclusions, and avenues for future work occupy section 6 .

\section{LITERATURE REFERENCE}

\section{Characteristics and constraints to entrepreneurship}

Constraints faced by entrepreneurs can be broadly classified into physical and emotional (Welpe, et. al 2012.); former e.g. include access to capital, business premises, prospective partners and latter include psychological factors such as emotional robustness to undertake a venture. It can be argued that in many instances both physical and emotional constraints could be very much intertwined as Smith and Beasley (2011) found that factors in their study constraining entrepreneurs included lack of general business knowledge, conflicting advice from external agencies, lack of mentorship and finance. Of all the physical factors, access to capital funds is a commonly cited reason that comes in the way of a budding entrepreneur. Praag et al (2005) found that initial capital constraints during the start-up phase of business have quite substantial negative influence on performance: the chance of survival of capital-constrained entrepreneurs appears to be about $50 \%$ less, while those surviving earn on average about $50 \%$ less. There are three key criteria that Venture Capitalists (VC) use to determine the level of financing offered and how this financing would be structured: confidence in the entrepreneur, confidence in the venture, and potential control of the VC over the venture (Payne, et.al. 2009; Zacharakis and Meyer 2000; MacMillan, Siegel, and Narasimha 1985; MacMillan, et. al. 1987).

There is an increasing recognition that the presence of unique resources is critical to a firm's success (West and Noel 2009; Florin, et.al. 2003; Yli-Renko, Autio, and Sapienza 2001; Tsai and Ghoshal 1998). Specifically, the resource-based view (RBV) of the firm suggests that if the firm can develop resources (tangible or intangible) that are immobile, valuable, rare, inimitable, and non-substitutable, they could lead to a rent-generating competitive advantage (Barney 1991; Conner 1991). Successful exploitation of a new product or service is dependent on such resources as access to enabling technologies, a capable management team, and sufficient stakeholder support (Choi and Shepherd 2004). Therefore, the presence of durable and immobile resources (Amit and Schoemaker 1993) increase the VC's level of confidence and, subsequently, the VC's willingness to invest in the venture. If the VC feels confident in the motivations, skills, and capabilities of the entrepreneur or entrepreneurial team, then higher levels of funding will be offered to the entrepreneur, all else being held equal. Furthermore, this confidence in the entrepreneur or entrepreneurial team can serve as a motivator for investment by the VC even when the confidence of the VC in the venture itself is not high (Payne, et. al. 2009). Hall and Hofer (1993) investigated 38 variables that measured different entrepreneurial behaviors, only three measures were significant predictors: Entrepreneurs who devoted more effort to (1) working with established suppliers or subcontractors; and those who (2) analyzed potential new entrants were more likely to start a new venture that survived; also entrepreneurs who devoted less effort to (3) determining the identity of their business were more likely to start a new venture that survived.

\section{Knowledge, Skill, and Experience}

West and Noel (2009) found that knowledge resources are critical in new ventures because they are the first type of resource that any successful new venture accumulates. These knowledge resources include the understanding of how to start up new organizations, how to manage people and processes, how to attain growth and competitive position, and how to stage technology and new product development (Brush, et. al., 2001). There are three types of procedural knowledge (Wiklund and Shepherd, 2003) important to new venture founders: (1) knowledge about the specific industry in which the new venture will compete; (2) knowledge about the type of strategic or business approach that the new venture might take within the industry; and (3) knowledge about creating and starting up new ventures. Familiarity with a similar kind of strategic approach and internal organization of the entrepreneur improves the quality of decisions. Hence, where which type of knowledge that is required for the new venture is highly related to the previous experience of the entrepreneur, the venture should have a higher probability of success. On the other hand, where an entrepreneur brings knowledge to a new venture that is unrelated to that necessary for the venture, there should be a higher risk of failure (West and Noel, 2009). The entrepreneur who has previous start-up experience would understand what steps to take in order to maximize the new venture's potential and therefore will be more confident (Westhead, et. al. 2005). 


\section{Networking}

In order to resolve uncertainty, entrepreneurs rely more heavily on external networks than do managers of older firms (McGee and Sawyer 2003), which is generative of both tacit and explicit knowledge that is helpful for the venture (Chrisman and McMullen, 2004). Entrepreneurs may supplement any industry, business, or previous start-up knowledge they have gained through experience with additional knowledge gained through networking (Johannisson 2000; Dubini and Aldrich 1991). Through networking, new and more valuable information can be provided to entrepreneurs and this information may assist them in their efforts to start, manage, and grow the company.

New ventures have a greater propensity to fail than do mature firms, in part, because they neither have wellestablished relationships and connections nor standardized efficient routines (Stinchcombe 1965). Relationships and connections of individuals in the entrepreneurial start-up are critical to helping to create and support these routines. The absence of relationships and routines has been recognized as resulting in a "liability of newness" for start-up firms (Li and Guisinger 1991; Freeman, et. al. 1983). Intangible assets such as social capital is the degree to which an organization has relationships that allow it to collaborate and cooperate (through such mechanisms as networks, shared trust, norms, and values) to achieve mutual benefits (Putnam 2000). These intangible assets are not easily copied, and thus, are widely recognized as having a greater potential to create a competitive advantage for the firm. This advantage is particularly important for the prestart-up and initial founding period of the firm (Nahapiet and Ghoshal 1998; Liebeskind 1996; Kogut and Zander 1988). Thus, the social capital of the firm would appear to be an important part of the survival of the new entrepreneurial venture (Neergaard and Madsen 2004). The fact that relationships are unique would appear to make them a particularly powerful type of intangible asset with great potential to offer a competitive advantage for this new entrepreneurial venture (Bamford, at. al. 2006).

\section{METHODS}

Following on from literature reference cited above and the scholarly works of Payne, Davis, Moore, and Bell (2009), Gartner and Starr (1999), Hall and Hofer (1993), Zacharakis and Meyer (2000), for the entrepreneur/team characteristics, hypotheses related to following traits were deduced for the purpose of empirical work in this paper: (1) extensive knowledge, skills, and experience; (2) entrepreneurial personality; (3) networking; and respect of third parties (Status and Public Media).

\section{General}

The focus of the paper is on the determination of characteristics that contribute towards the fear of starting a new venture. We hypothesize that business start-ups are influenced by a set of personal and social factors that include the age and the gender of the person. We hypothesize that younger male respondents would be less fearful of failure in starting a business of their own. Those respondents who have requisite skills and are networked (irrespective of their age and gender) would be less fearful as well. On the social side, if entrepreneurs are eulogized in the media and self-employment is considered to be a desirable career choice and held in high esteem in the society then these social traits would impact negatively on the fear factor. A failed business venture in the recent past and the thought of starting a new business might impact positively ('feed into fear') on the question in hand.

\section{Culture-Specific}

We specify two culture-specific hypotheses. First, given the tightly knit social networks, we hypothesize that career choice, status, and praises in media about owing personal business would impact negatively on the question in hand in the case of Brazil. That is, these factors will be what can loosely be called 'fear reducing'. We do not expect to see any difference in results with regard to age, gender, skill, and networking and expectations in the case of two countries. A failed business venture in the near past can add to the 'fear factor' of starting another new business, particularly in the case of Brazil in which losing face among family and society members would be taken more seriously.

\section{DATA AND VARIABLES}

\section{Data source}

The data used in the study comes from the Global Entrepreneurship Monitor (GEM). GEM began in 1999 as a joint project between Babson College (USA) and London Business School (UK). The aim is to consider why some countries are more 'entrepreneurial' than others. Presently, GEM is the richest resource of information on 
the subject. Database is aimed at measuring the differences in the level of early-stage entrepreneurial activity between countries; uncover factors determining the levels of entrepreneurial activity, and identify policies that may enhance the level of entrepreneurial activity. The data is made public with a three-year lag. The data used in this paper is for 2005 (details can be had at https://www.gemconsortium.org/data).

\section{Methodology}

The methodology adopted to test the hypotheses stated above is the Logit regression model of the following kind.

$$
\operatorname{Logit}(Y)=\operatorname{In}\left(\frac{\pi}{1-\pi}\right)=\alpha+\beta 1 X 1+\beta 2 X 2+\cdots \ldots \ldots \ldots \ldots+\beta n X n+\epsilon_{i}+
$$

Where $\pi=$ Probability $(Y=$ probability that fear of failure will prevent a start-up $) \mid X_{1}=\mathrm{x}_{1}, X_{2}=\mathrm{x}_{2} \ldots . .$,

$$
X n=x n=\frac{e^{\alpha+\beta 1 X 1+\beta 2 X 2+\cdots \ldots \ldots \ldots . . .+\beta n X n}}{1+e^{\alpha+\beta 1 X 1+\beta 2 X 2+\cdots \ldots \ldots \ldots \ldots . .+\beta n X n}}
$$

Where $\pi$ is the probability of the event, $\alpha$ is the $Y$-intercept, $\beta_{s}$ are the regression coefficients, and $X_{s}$ are a set of predictors; $\alpha$ and $\beta_{s}$ are estimated by the maximum likelihood (ML) method. The null hypothesis underlying the overall model is that all $\beta_{s}$ are zero. A rejection of the null hypothesis implies that at least one $\beta$ does not equal zero in the population, i.e., the logistic equation predicts the probability of the outcome better than the mean of the dependent variable $Y$. The dependent variable comes from the following questions asked to respondents: "Fear of Failure would prevent you from starting a business?" Responses were coded as unitary value for 'yes' and zero for 'no'. As for predictor variables, the following nine variables were chosen from the database.

Person specific variables:

1. Age $=$ Independent: Age group (young $\leq 34$ years old: coded 1$)$ vs. older ( $\geq 35$ : coded 0 ).

2. Gender $=$ Gender Male $=1$, Female $=0$.

The following questions were coded unitary values for 'yes' and zero for a 'no' answer.

3. Skills = 'you have the knowledge, skill, and experience required to start a new business?'

4. Networking = 'you know someone personally who started business in the past two years?'

Social-status related variables:

The following questions that were asked were coded unitary values for 'yes' and zero for a 'no' answer.

5. CareerChoice $=$ 'in your country, most people consider starting a new business a desirable career choice?

6. Status = 'in your country the successful at starting a new business have a high level

of status and respect?'

7. Media = 'in your country you very often see stories in the public media about successful new businesses?'

Psychology-related variables:

The following questions were coded unitary values for 'yes' and zero for a 'no' answer.

8. Expecting = 'you alone or with others expecting to start a new business including any type of selfemployment within the next 3 years?'

9. Closure = 'you have in the past 12 months shut down, discontinued, or quit a business you owned and managed, any form of self-employed or selling goods or services to anyone?'

\section{RESULTS}

\section{Descriptive results}


Tables-1 and 2 report means, standard deviations, and zero-order correlations. In the case of the UK entrepreneurs, fear of failure that would prevent someone starting a business is positively correlated with 'young age' and negatively correlated with 'male' respondents and with the fact that the respondent has the 'requisite know-how and skills' to start a business. Past failures and positive thought of starting a new business in the future are 'fear reducing' for British entrepreneurs. But being in the limelight by acquiring status is positively correlated with the 'fear' factor for the UK males. For Brazilian entrepreneurs, being young, skilled, and expectation of starting a new venture in the near future is negatively correlated with the fear factor. But the social status that comes with running own business is positively correlated with the fear factor. These descriptive results are by and large confirmed when we subject the data to multivariate analysis.

Table1. Basic statistics and zero-order correlations of Independent Variables (UK)

\begin{tabular}{|c|c|c|c|c|c|c|c|c|c|c|c|c|}
\hline UK & Mean (SD) & & 1 & 2 & 3 & 4 & 5 & 6 & 7 & 8 & 9 & 10 \\
\hline FearFailure & $.33(.471)$ & 1 & 1 & & & & & & & & & \\
\hline Age & $.26(.440)$ & 2 & $.057^{\star \star}$ & 1 & & & & & & & & \\
\hline Gender & $.41(.492)$ & 3 & $-.047^{\star *}$ & -0.005 & 1 & & & & & & & \\
\hline Skills & $.49(.500)$ & 4 & $-.155^{\star *}$ & $-.043^{\star *}$ & $.193^{* *}$ & 1 & & & & & & \\
\hline Networking & $.27(.444)$ & 5 & -0.006 & $.100^{\star *}$ & $.104^{* *}$ & $.213^{* *}$ & 1 & & & & & \\
\hline CareerChoice & $.49(.500)$ & 6 & 0.039 & $.131^{* *}$ & $.028^{*}$ & 0.006 & -0.021 & 1 & & & & \\
\hline Status & $.67(.468)$ & 7 & $.044^{*}$ & $.084^{* \star}$ & 0.013 & 0.013 & 0.009 & $.225^{* *}$ & 1 & & & \\
\hline Media & $.56(.496)$ & 8 & 0.035 & $-.045^{\star *}$ & $.025^{*}$ & $.057^{* \star}$ & 0.024 & $.128^{\star *}$ & $.130^{* *}$ & 1 & & \\
\hline Expecting & $.06(.236)$ & 9 & $-.059^{* *}$ & $.094^{\star *}$ & $.087^{* *}$ & $.200^{* *}$ & $.191^{* *}$ & $.052^{* *}$ & 0.020 & 0.024 & 1 & \\
\hline Closure & $.01(.121)$ & 10 & $-.029^{*}$ & -0.015 & $.059^{* *}$ & $.126^{* *}$ & $.085^{\star *}$ & 0.008 & 0.000 & 0.005 & $.081^{* \star}$ & 1 \\
\hline
\end{tabular}

${ }^{* *}$. Correlation is significant at the 0.01 level; *. Correlation is significant at the 0.05 level (in a 2-tailed test).

Table 2. Basic statistics and zero-order correlations of Independent Variables (Brazil)

\begin{tabular}{|c|c|c|c|c|c|c|c|c|c|c|c|c|}
\hline Brazil & Mean (SD) & & 1 & 2 & 3 & 4 & 5 & 6 & 7 & 8 & 9 & 10 \\
\hline FearFailure & $.37(.482)$ & 1 & 1 & & & & & & & & & \\
\hline Age & $.50(.500)$ & 2 & $-.074^{\star *}$ & 1 & & & & & & & & \\
\hline Gender & $.48(.500)$ & 3 & -0.047 & 0.006 & 1 & & & & & & & \\
\hline Skills & $.53(.499)$ & 4 & $-.096^{\star *}$ & $-.051^{*}$ & $.134^{* *}$ & 1 & & & & & & \\
\hline Networking & $.41(.493)$ & 5 & -0.012 & $.127^{\star *}$ & $.113^{* *}$ & $.244^{* *}$ & 1 & & & & & \\
\hline CareerChoice & $.73(.443)$ & 6 & 0.032 & 0.005 & 0.002 & $.125^{* *}$ & 0.017 & 1 & & & & \\
\hline Status & $.71(.454)$ & 7 & $.072^{*}$ & -0.013 & $.076^{* *}$ & 0.024 & 0.032 & $.269^{* *}$ & 1 & & & \\
\hline Media & $.68(.465)$ & 8 & -0.025 & 0.016 & 0.040 & $.092^{* *}$ & 0.053 & $.271^{\star *}$ & $.333^{* *}$ & 1 & & \\
\hline Expecting & $.23(.422)$ & 9 & $-.081^{* *}$ & $.120^{\star *}$ & 0.040 & $.212^{* *}$ & $.158^{\star *}$ & $.098^{* \star}$ & $.105^{\star *}$ & $.060^{*}$ & 1 & \\
\hline Closure & $.06(.232)$ & 10 & 0.027 & $.044^{\star}$ & 0.027 & $.091^{* *}$ & $.104^{* \star}$ & 0.045 & 0.001 & 0.011 & $.187^{* *}$ & 1 \\
\hline
\end{tabular}

${ }^{* *}$. Correlation is significant at the 0.01 level. *. Correlation is significant at the 0.05 (in a 2-tailed test).

\section{Multivariate results on hypotheses}

Table-2 reports the results of multivariate logistic regressions. Our first general hypothesis that younger and male entrepreneurs are less fearful in starting their own venture is supported (save for British entrepreneurs for whom age factor does not come out as relevant). With regard to the second hypothesis that respondents with requisite skills and those who are networked would be less fearful in starting a venture, only skill factor comes out to be significant, thus only partially supporting the second hypothesis. In our third hypothesis, we stated that situations, where self-employment is considered a preferred choice and where media showers praise on entrepreneurs, would lead to reduction in fear of starting a new business. Here results are rather counterintuitive; for British entrepreneurs they seem to add to the fear factor and for Brazilian entrepreneurs media publicity seems to lead to a reduction in fear factor and but career choice as the independent operator does not come out to be a significant factor. Finally with regard to the fourth hypothesis that failed past ventures and the thought of starting a new business again would create a fear psychosis yielded mixed results. Whereas in the case of British entrepreneurs, thought of starting a new business seems to be invigorating, leading to reduction in fear, such a thought has no impact on Brazilian entrepreneurs, but past failures of business add to the fear of starting another business; whereas it has no impact on British entrepreneurs. 
Table 3. Estimates of Logistic Regressions. Dependent variable: Probability that fear of failure prevents starting a business.

\begin{tabular}{|c|c|c|}
\hline \multirow{2}{*}{ PREDICTORS } & UK & Brazil \\
\hline & Coefficients (significance) & Coefficients (significance) \\
\hline \multicolumn{3}{|l|}{ PERSONAL: } \\
\hline $\begin{array}{l}\text { 1. Age: (young-up to } 34 \text { years: Vs. older } 35 \text { and } \\
\text { over). }\end{array}$ & $\begin{array}{l}0.012 \\
(0.90)\end{array}$ & $\begin{array}{c}-0.753^{\star *} \\
(0.00)\end{array}$ \\
\hline 2. Gender $($ Male $=1$, Female $=0$ ) & $\begin{array}{c}-0.218^{* *} \\
(0.01)\end{array}$ & $\begin{array}{c}-0.286^{*} \\
(0.05)\end{array}$ \\
\hline $\begin{array}{l}\text { 3. Skills: You have the knowledge, skill, and } \\
\text { experience required to start a new business? }\end{array}$ & $\begin{array}{c}-0.847^{* *} \\
(0.00)\end{array}$ & $\begin{array}{c}-0.712^{* *} \\
(0.00)\end{array}$ \\
\hline \multicolumn{3}{|l|}{ SOCIAL STATUS: } \\
\hline $\begin{array}{l}\text { 4. Networking: You know someone personally } \\
\text { who started business in the past two years? }\end{array}$ & $\begin{array}{l}0.031 \\
(0.74)\end{array}$ & $\begin{array}{l}0.073 \\
(0.63)\end{array}$ \\
\hline $\begin{array}{l}\text { 5. Career Choice: In your country, most people } \\
\text { consider starting a new business as a desirable } \\
\text { career choice? }\end{array}$ & $\begin{array}{l}0.144^{1} \\
(0.13)\end{array}$ & $\begin{array}{l}0.230 \\
(0.21)\end{array}$ \\
\hline $\begin{array}{l}\text { 6. Status: In your country, the successful at } \\
\text { starting a new business have a high level of } \\
\text { status and respect? }\end{array}$ & $\begin{array}{l}0.184^{\star} \\
(0.08)\end{array}$ & $\begin{array}{l}0.451^{*} \\
(0.02)\end{array}$ \\
\hline $\begin{array}{l}\text { 7. Media: In your country, you very often see } \\
\text { stories in the public media about successful new } \\
\text { businesses? }\end{array}$ & $\begin{array}{l}0.184^{*} \\
(0.053\end{array}$ & $\begin{array}{c}-0.252^{1} \\
(0.15)\end{array}$ \\
\hline \multicolumn{3}{|l|}{ PSYCHOLOGY RELATED: } \\
\hline $\begin{array}{l}\text { 8. Expecting: You alone or with others } \\
\text { expecting to start a new business including any } \\
\text { type of self-employment within the next } 3 \text { years? }\end{array}$ & $\begin{array}{c}-0.188^{*} \\
(0.08)\end{array}$ & $\begin{array}{l}-0.179 \\
(0.24)\end{array}$ \\
\hline $\begin{array}{l}\text { 9. Closure: You have in the past } 12 \text { months shut } \\
\text { down, discontinued, or quit a business you } \\
\text { owned and managed, any form of self-employed } \\
\text { or selling goods or services to anyone? }\end{array}$ & $\begin{array}{l}-0.036 \\
(0.85)\end{array}$ & $\begin{array}{l}0.492^{*} \\
(0.02)\end{array}$ \\
\hline Model fitting statistics & $\begin{array}{l}-2 \text { Log likelihood }=1076.350 \\
\text { Cox \& Snell } R^{2}=0.066 \\
\text { Nagelkerke } R^{2}=0.092\end{array}$ & $\begin{aligned}-2 \text { Log likelihood } & =2846.417 \\
\text { Cox \& Snell } R^{2} & =0.039 \\
\text { Nagelkerke } R^{2} & =0.056\end{aligned}$ \\
\hline
\end{tabular}

Significance levels in brackets. ${ }^{*}$ significant at the 0.01 level ${ }^{*}$ significant at the $0.05-.10$ levels; ${ }^{1}$ significant at .15 level.

With regard to culture-specific hypotheses we had hypothesized that given tightly knit social networks, career choice as an entrepreneur, status that it brings with it, and praise in media about owning a business will be 'fear reducing' in the case of Brazil. But it is only the last factor (media praise) that leads to a reduction in fear; in fact, social status, no matter how important it is in its own right, adds to fear of starting a business; network benefits and preferred career choice do not come out to be significant. However, as expected, past business failures do enhance the fear factor, as losing face second time would perhaps be too much for prospective entrepreneurs.

\section{SUMMARY, CONCLUSIONS, AND AVENUES FOR FUTURE WORK}

People become entrepreneurs for a variety of reasons. In a similar analogy, people may also choose not to become entrepreneurs. The underlying reasons for people not choosing to take the entrepreneurial route can be complex ranging from purely personal (in-built fear of failure), social (excessive pressure from society to succeed), financial (lack of available finance), technical (lack of access to suitable technology at affordable price), markets (paucity of outlets for the product produced), or they could purely be institutional (ease of obtaining licenses, e.g.). In this paper, we tested a model of fear of failure of starting a business by groups of entrepreneurs in the UK and Brazil. We attributed the 'fear' factor to a set of personal, social and psychological reasons. We found several interesting results pertaining to entrepreneurial character in general and culturespecific in particular. Some of the echoes from Hofstede's cultural dimensions can be heard in the results. We can also see elements of convergence of results with regard to two countries. 
Empirical results show that both British and Brazilian males, when they are skilled are less afraid to start a new venture. Results also show that this could be owing to a high status accorded in both the countries to new business start-ups. However, whereas media publicity may add to the fear factor of starting a business in the case of British entrepreneurs; it lessens the fear in the case of Brazilian entrepreneurs. Past failures seem to have no impact on British entrepreneurs, but such failures do seem to add to the fear in Brazilian entrepreneurs. Positive planning to start a new business adds to optimism for British entrepreneurs.

Contrary to UK males, younger Brazilian males are also less fearful of starting a new business. This particular result which is highly significant in the case of Brazilian entrepreneurs does convey the message of a growing economy in which young entrepreneurs are increasingly inclined to take their chances in initiating new businesses. Thus this trait could be partly cultural and partly driven by growing opportunities in the country.

What is a little bit surprising is that the virtues of networking or the fact that society places a high value on being an entrepreneur do not show up significantly in the model. The plausible explanations for these could be the emerging rugged nature of the modern entrepreneur whose information is now widely available by electronic media and who really does not worry much as to how his entrepreneurial venture is perceived by the society. He works more for his own goals and satisfaction. If all goes well he would be noticed-if not then he will start again.

This exploratory work can be extended in several directions. For instance, similar analyses could be conducted for other countries and for additional years for which GEM data is available. Inter-country and intra-country analysis of this nature could particularly be useful. Additionally, similar analyses could be conducted within Hofstede's (1985) framework of cultural dimensions. Finally, the GEM database also permits longitudinal studies.

\section{REFERENCES}

Aldrich, H. E., \& Wiedenmayer, G. (1993). From traits to rates: An ecological perspective on organizational foundings, in Katz, J., \& Brockhaus, R. (Eds.), Advances in Entrepreneurship, Firm Emergence, and Growth. Conn.: JAI Press, Greenwich, 145-95.

Alstete, J.W. (2003). On becoming an entrepreneur: An evolving typology. International Journal of Entrepreneurial Behaviour \& Research, 8(4), 222-34.

Amit, R., \& Schoemaker, P. (1993). Strategic assets and organizational rent, Strategic Management Journal, 14, 33-46.

Bamford, E. C., Bruton, G. D., \& Hinson, Y. L. (2006). Founder/chief executive officer exit: A social capital perspective of new ventures. Journal of Small Business Management, 44(2), 207-220.

Barney, J. (1991). Firm Resources and Sustained Competitive Advantage. Journal of Management, 17(1), 99- 120.

Begley, T.M., \& Boyd, D.P (1986). Psychological characteristics associated with entrepreneurial performance, In Ronstadt, R., Hornaday, J., Peterson R., \& Vesper, K. (Eds.). Frontiers of entrepreneurship research, Babson Park, MA. US: Babson College, 146-65.

Brush, C. G., Greene, P. G., \& Hart, M. M. (2001). From initial idea to unique advantage: The entrepreneurial challenge of constructing a resource base. Academy of Management Executive, 15(1), 64-78.

Casson, M. (2003). The Entrepreneur: An economic theory, Cheltenham, UK: Edward Elgar.

Casson, M.(2008). Entrepreneurship, in The Concise Encyclopaedia of Economics,

http://www.econlib.org/library/Enc/Entrepreneurship.html.

Chandler, G. N., \& Jansen, E. (1992).The founder's self-assessed competence and venture performance. Journal of Business Venturing, 7(3), 223-36.

Choi, Y. R, \& Shepherd, D. A. (2004). Entrepreneurs, decisions to exploit opportunities. Journal of Management, 30, 377395.

Chrisman, J. J., \& McMullen, W. E. (2004). Outsider assistance as a knowledge resource for new venture survival. Journal of Small Business Management, 42(3), 229-244.

Conner, K. (1991). A historical comparison of resource-based theory and five schools of thought within industrial organization economics: Do we have a new theory of the firm? Journal of Management, 17(1), 121-155.

Doobs, M \& Hamilton, R.T. (2007). Small business growth: Recent evidence and new directions, International Journal of Entrepreneurial Behaviour and Research, 13 (5), 296-322.

Dubini, P., and Aldrich, H. (1991). Personal and extended networks are central to the entrepreneurial Process. Journal of Business Venturing, 6(5), 305-313.

Florin, J., Lubatkin, M., \& Schulze, W. (2003). A social capital model of high growth ventures. Academy of Management Journal, 46(3), 374-384.

Freeman, J., Carroll G. R., \& Hannan, M. T. (1983). The liability of newness: Age dependence in organizational death rates. American Sociological Review, 48, 692-710. 
West, P.G., Noel, T (2009). The impact of knowledge resources on new venture performance. Journal of Small Business Management, 47(1), 1-22.

Gartner, W. B., \& Starr, J. A. (1999). Predicting new venture survival: An analysis of the anatomy of a start-up, cases from Inc. Magazine. Journal of Business Venturing, 14, 215-233.

Global Entrepreneurship Monitor (GEM) https://www.gemconsortium.org/data.

Gilad, B. \& Levine, P. (1986). A behavioural model of entrepreneurial supply, Journal of Small Business Management, 24(4), 45-54.

Hall, J., \& Hofer, C. W. (1993). Venture capitalists, decision criteria in new venture evaluation. Journal of Business Venturing, 8, 25-42.

Hofstede, G. (1985). The interaction between national and organizational value systems. Journal of Management Studies, $22(4), 347-357$.

Johannisson, B. (2000). Networking and entrepreneurial growth in the Blackwell Handbook of entrepreneurship. Eds. D. L. Sexton and H. Landström. Malden, MA: Blackwell Publishers, 368-386.

Kirzner, I. M. (1973). Competition and entrepreneurship. Chicago: University of Chicago Press.

Kirzner, I. M. (1979). Perception, opportunity, and profit: studies in the theory of entrepreneurship. Chicago: University of Chicago Press.

Knight, F.H. (1921). Risk uncertainty and profit, Chicago: University of Chicago Press.

Kogut, B., \& Zander, U. (1988). Knowledge of the firm, combinative capabilities, and the replication of technology. Organization Science, 3(3), 383-397.

Li, J., \& Guisinger, S. (1991). Comparative business failures of foreign controlled firms in the United States. Journal of International Business Studies, 22(2), 209-224.

Liebeskind, J. P. (1996). Knowledge, strategy, and the theory of the firm. Strategic Management Journal, $17,93-107$.

Littunen, H. (2000). Entrepreneurship and the characteristics of the entrepreneurial personality, International Journal of Entrepreneurial Behaviour and Research, 6 (6), 295-310.

Lumpkin, G.T. \& Dess, G. G. (1996). Clarifying the entrepreneurial orientation construct and linking it to performance. Academy of Management Review, 21(1), 135-72.

MacMillan, I. C., Zemann, L., \& Narasimha, P. N. S. (1987). Criteria distinguishing successful from unsuccessful ventures in the venture screening process. Journal of Business Venturing, 2, 123-137.

MacMillan, I. C., Siegel, R., \&. Narasimha (1985). Criteria used by venture capitalists to evaluate new venture proposals. Journal of Business Venturing, 1, 119-128.

McClelland, E., Swail, J., Bell. J. \& Ibbotson, P. (2005). Following the pathway of female entrepreneurs: A six-country investigation. International Journal of Entrepreneurial Behaviour and Research, 11(2), 84-107.

McGee, J. E., \& Sawyer O. (2003). Uncertainty and information search activities: A Study of owner-managers of small hightechnology manufacturing firms. Journal of Small Business Management, 41(4), 385-401.

Mckay, R. (2001).Women entrepreneurs: Moving beyond family and flexibility. International Journal of Entrepreneurial Behaviour and Research, 7(4), 148-65.

Mordi C., Simpson, R., Singh, S., \& Okafor, C., (2010). The role of cultural values in understanding the challenges faced by female entrepreneurs in Nigeria. Gender in Management: An International Journal, 25(1), 5-21.

Morrisson, A. (2000). Entrepreneurship: What triggers it? International Journal of Entrepreneurial Behaviour and Research, $6(6), 59-71$.

Nahapiet, J., \& Ghoshal, S. (1998). Social Capital, intellectual capital, and the organizational advantage. Academy of Management Review 23, 242-266.

Neergaard, H., \& Madsen, H. (2004). Knowledge-intensive entrepreneurship in a social capital perspective. Journal of Enterprising Culture, 12, 105-125.

Orhan, M., \& Scott, D. (2001). Why women enter into entrepreneurship: an explorative model. Management Review, 16 (5), 232-47.

Payne, G. T., Davis J. L., Moore, C. B., \& Bell, R.G. (2009). The deal structuring stage of the venture capitalist decisionmaking process: Exploring confidence and control. Journal of Small Business Management, 47(2), 154-179.

Praag, M.V., Wit, G.D., \& Bosma, N., (2005) Initial capital constraints hinder entrepreneurial venture performance. Journal of Private Equity, 9(1), 36-44.

Putnam, R. D. (2000). Bowling Alone. The collapse and revival of American community. New York: Simon \& Schuster.

Schumpeter, J. A. (1911). The theory of economic development. New Brunswick Transaction Publishers.

Schumpeter, J.A. (1954). History of economic analysis. London: Routledge.

Singh, S., Mordi, C., \& Okafor C. (2010). Family legacy and female entrepreneurs: Insights from Nigeria. International Journal of Management Practice, 4(3), 273-292. 
Singh S., Mordi, C., Okafor, C., \& Simpson, R. (2011). Challenges in female entrepreneurial development. Journal of Enterprising Culture, 18(4), 435-460.

Singh, S., Simpson, R., Mordi, C., \& Okafor, C. (2011). Motivation to become an entrepreneur: A study of Nigerian women's decisions. African Journal of Economics and Management Studies, 2(2), 202-219.

Smith, K., \& Beasley, M (2011). Graduate entrepreneurs intentions, barriers \& solutions. Education + Training, 53(8/9), 722740.

Stinchcombe, A. L. (1965). Social structure and organizations. In Handbook of Organizations. Ed. James G. March. Chicago, IL: Rand McNally, 142-193.

Tsai, W., \& Ghoshal S. (1998). Social capital and value creation: The role of intra firm networks. Academy of Management Journal 41(4), 464-477.

Watson, K., Hogarth-Scott, S., \& Wilson, N. (1998). Small business start-ups: Success factors and support implications. International Journal of Entrepreneurial Behaviour and Research, 4(3), 217-238.

Welpe, I. M et. al. (2012). Emotions and Opportunities: The Interplay of Opportunity Evaluation, Fear, Joy, and Anger as Antecedent of Entrepreneurial Exploitation. Entrepreneurship Theory and Practice. 36 (1): 69-96.

Westhead, P., Ucbasaran, D., Wright, M (2005). Decisions, Actions, and Performance: Do Novice, Serial, and Portfolio Entrepreneurs Differ? Journal of Small Business Management. 4394), 393-417.

Wiklund, J Shepherd, D (2003). Knowledge-based resources, entrepreneurial orientation, and the performance of small and medium-sized businesses. Strategic Management Journal. 24(13), 1307-1314.

Yli-Renko Helena, Autio, E, Sapienza H (2001). Social capital, knowledge acquisition, and knowledge exploitation in young technology-based firms. Strategic Management Journal. 22(6-7), 587-613.

Zacharakisa, A. I. and Dale Meyer G.D. (2000). The potential of actuarial decision models: Can they improve the venture capital investment decision? Journal of Business Venturing. 15 (4), 323-346. 